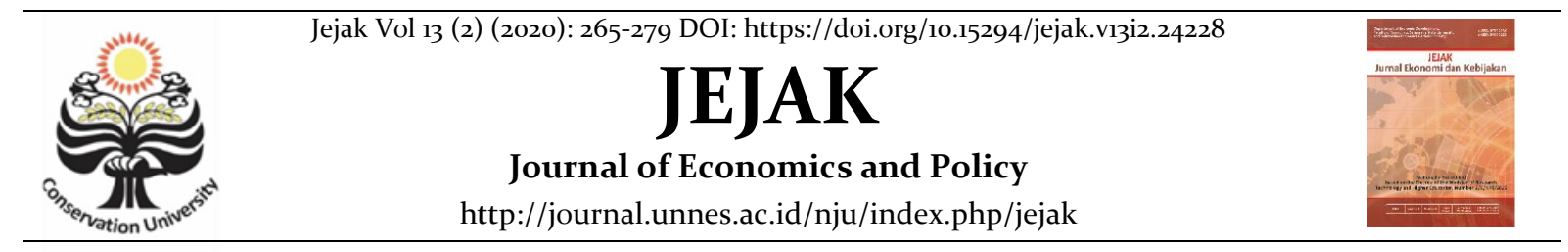

\title{
Corruption and Economic Growth in West Africa
}

\author{
Clement Atewe Ighodaro ${ }^{\circledR}$, ${ }^{2}$ Sunday Osahon Igbinedion \\ ${ }^{1,2}$ Departement of Economics, Faculty of Social Sciences, University of Benin, Benin City, Nigeria \\ Permalink/DOI: https://doi.org/10.15294/jejak.v13i2.24228
}

Received: May 2020; Accepted: July 2020; Published: September 2020

\begin{abstract}
The level of corruption in West Africa has become very worrisome based on the data from the corruption perception index of transparency international. Corruption may subvert due process; reduce accountability; lead to unequal distribution of goods and services and limit the reliance of the masses on government. The objective of the paper was to examine the link between corruption and economic growth in West Africa. Data used span from 2000 to 2018 with a cross section of fifteen West Africa countries and the use of panel fully modified ordinary least squares. With the use of the Im, Pesaran, and Shin stationarity which allows for heterogeneous version of the Dickey Fuller test, it was found that the variables used were integrated of order one and long run equilibrium relationship existed based on the Pedroni cointegration method. Only foreign direct investment did not meet the a priori expectation. The result supports the 'grease on the wheel hypothesis'. This implies that corruption and economic growth have direct relationship in West Africa. Corruption and economic growth were found to also support the U-shaped hypothesis which means that different corruption level affect economic growth in different ways. However, corruption does not lead to efficient and effective outcomes hence should not be allowed at any level of governance.
\end{abstract}

Key words : Corruption, Economic Growth, Panel FMOL, U-Shaped Hypothesis, West Africa

How to Cite: Ighodaro, C., \& Igbinedion, S. (2020). Corruption and Economic Growth in West Africa. JEJAK: Jurnal Ekonomi dan Kebijakan, 13(2), 265-279. doi:https://doi.org/10.15294/jejak.v13i2.24228 


\section{INTRODUCTION}

The main interest for this paper is anchored on the premise that corruption is becoming a public issue in West Africa as policy makers, economic and political analysts as well as the general public have created great awareness on its bad effect to any economy. This awareness of corruption problem has taken centre stage in the news and print media which in turn has prompted several questions as to the effect of corruption on economic growth of West Africa. Corruption helps to waste resources through weak and non - transparent procurement policy, non-transparent allocation of state subsidies and Misallocation of talent and resources and non transparency of regulations (World Bank, 1997). In 2009, the African Union reported that corruption drained the region of some $\$ 140$ billion a year, which according to Ribadu (2009) is about $25 \%$ of Africa's official GDP. Corruption, particularly, political and public sector corruption has been a major problem in West Africa. It is widespread in the societies where poverty and unemployment are high and the masses have lost government trust which has led to widespread crime and political unrest. The report from the corruption perception index of 2018 revealed that several countries have no impressive results despite government efforts which in some cases are cosmetic because it creates more corrupt act through bribery.

The report is even worse for West African countries because from the Transparency International report on corruption of 2018 , out of the 16 countries in the region, Nigeria had 27 out of 100 while Ghana scored 41, Cabo Verde scored the highest in West Africa with a 57 out of 100, though, on the average, West Africa ranges about 30\% (Corruption Perceptions Index,
2018). West African countries have been facing corruption as one of her major problem to the extent that some policy holders have been using all possible strategies to fight the menaces globally and regionally through for example, the regulation of public procurement and the establishment of courts of audit. Corruption has led to wide spread criminality and poverty as well as unemployment through nepotism.

Consensus has not been established on the empirical relationship between corruption and economic growth for panel of countries while related studies in West Africa are not common. However, theoretical justification remains ambiguous. Empirical evidences with the use of different panel estimation methods by Boussalham (2018); Gründler \& Potrafke (2019); Tidiane (2019) established inverse relationship between corruption and economic growth for 160 countries; 175 countries and WAEMU region, respectively. This implies that corruption sands the wheel of economic growth in the countries. On the other hand, Saha and Sen (2019) found positive relationship and concluded that corruption and economic growth have direct relationship in autocracies as compared to democracies.

As noted by Gorai (2016), corruption can be conceptualized based on the perception of the researcher; hence Theobald \& Williams (1999) opined that the definition of corruption is complex because it is not tied to any disciplinary allegiance. For example, corruption in the public sector is the misused of entrusted authority for private gains (Seldadyo \& De Haan, 2006). Corruption occurs in several forms like dishonesty, fraud, bribery, embezzlement, blackmailing, nepotism and favouritism which occurs in different sectors of the economy. There are two schools of taught with respect to the relationship between corruption and economic growth. The first one is of the opinion that corruption propels economic growth through tips and briberies which reduces bureaucracies in organization known as "grease 
the wheels hypothesis" (Leff, 1964). The other noted that corruption decreases economic growth through prevention of efficiency in production and innovation known as "sand in the wheel hypothesis" (Mauro, 1998; Svensson, 2005).

There are several perspectives of corruption. According to Granovetter (1992), there is the moralist perspective of corruption. The moralist perspective involves the principal and the agent. The principals are the senior government officials who advise and implement governments' policy matters as well as plan, organize, direct, control and evaluate the overall activities governments and its departments. The junior personnel are the agents, and are those that are cleaners, messengers, those in the clerical cadre, drivers and sometime artisans that are believed to have some privileged information than the principals who may wish to pay illegally to have access to certain classified information that may not be officially meant for them. Booth (2012) further buttressed this by noting that the principal and the agent problem exist when either of them, most especially, the principal requires a service of the agent, but the principal does not have the necessary information to oversee the performance of the agent in an effective way. This information imbalance is as a result of asymmetry of information that arises because the agent has more or better information than the principal.

There are also the moralist and the functionalist perspectives of corruption. The moralist noted that corruption is an immoral behaviour which may make someone to lose his or her respect in the society (Gould, 2002). This is why Nye (1979) noted that corruption tends to be in favour of close family, private colleagues, among others which violate the existing rules. The functionalist views corruption as playing an important role in the society by speeding up some difficult process in administration (Johnston, 2000). Ayee (2002), Lo (1993) opined that the opinion of the functionalist perception is that it can create political access for those that are excluded, and perhaps even produce people that may assume power that they are not legally bound to have, particularly in certain government policies. One of the criticisms against the functionalists' perception is that they did not consider political power, individual interest and social structure in their discussion. They did not also consider the historical perspective of corruption.

One of the theories of corruption is the bad apple theory which considers corruption at the individual level. That is, corruption is determined by the kind of association you keep implying that bad behaviour begets bad behaviour and bad company begets bad company. This results from individual shortcomings like greed (de Graaf 2003). Bad apple theory is not very popular because corruption is almost a normal rather than abnormal. This is probably why Punch (2000) noted that corruption used to be thought of as a transient problem rather than permanent and referred to it as exceptional 'problem' which can only be removed by 'surgical' treatment, as if it was a malignant cancer, to restore an otherwise healthy agency (the 'bad apple' metaphor). Another one is the public choice theory that was made popular by Rose-Ackerman (1978). She noted that the public worker that is corrupt tries to maximize his potential gain from corrupt act, particularly when the potential benefit is greater than the potential cost. Hence, Klitgaard (1988) noted that people will continue to be corrupt when the advantages from being corrupt are bigger than the disadvantages.

The organizational culture theory is sociological perspective of corruption which discusses corruption as it relates to the way of life of the people in the organization, which is 
corruption at the macro level rather than the individual level. Meaning that agents that are not corrupt may become corrupt when they find themselves in a corrupt environment, that is corruption is the cause of corruption. This is probably why Jackall (1988); Punch (2000) opined that not becoming corrupt in certain organizational cultures means betraying the group. Hence, Huberts, Kaptein \& Lastuizen (2004) noted that to fight corruption in organisations, you alter the organisation' leadership.

Teveik, Albert, \& Charles (1986) propounded the policy-oriented theory of corruption from the perspectives of political science and economics with emphasis on government corruption. They noted that corruption not widely checked leads to more corruption and high level of corruption in any economy if not checked may hinder growth of the economy. Similarly, as noted by them, individual level corruption such as greed and the likelihood of detection and prosecution suggest one set of policies for reducing corruption. They opined that to deal with corruption problem in any society, bureaucratic challenges, slow justice and poor social demands of members of the society must be dealt with in analyzing corrupt practices.

Bernard, Snipes, \& Gerould (2010) opined that the social disorganization theory was propounded as part of the Chicago School, a body of theory which focuses on urban sociology in the 1920 s and 1930s. The theory is based on the assumption that the way people behave is influenced mostly by one's environment, and that corruption and other deviant and the environment one finds himself due to weak corruption control mechanism. The theory posits that unwarranted behaviour has cultural, political, and economic causes (Akers \& Sellers, 2009). Disorganized communities such as the case of some of the West African countries experience severe crimes and criminality because informal social controls break down. The theory predicts that more crime will occur in neighbourhoods with weak social structures, such as failing schools, vacant or vandalized buildings, changing ethnicity, and high unemployment (Steenbeek \& Hipp, 2011).

Johnson (1998) argued that corruption is embedded in the overall society in many countries based on the social disorganization theory. According to the author, in most countries, political and economic changes may introduce corruption rather than stop it. From the sociological perspective, the social learning theory is based on the assumption that the same learning process can lead to deviance in the society. The social disorganization theory posited that the interactions of variables like different associations, modelling, and reinforcement determine social behaviour (Singer \& Hensley, 2004). Akers \& Sellers (2009) opined that behaviour is determined by the standards of positive and negative reinforcement or rewards and punishment under the social learning theory, behaviour and the key variable is peer influence. Bernard, Snipes \& Gerould, (2010) suggested that social structure affects crime because it affects one's exposure to the rules and the consequences of violating such rules.

In empirical review, the prevalence of corruption in the society has been attributed to socio-economic factors amongst others factors. Mo (2001) used data for the period 1970 to 1985 and the ordinary least squares as well as the two stage least squares in Hong Kong. They found that the key channel through which corruption affect economic growth is through political instability. They also found that corruption also reduces human capital and share of private investment. Ahmed, Ullah \& Arfeen (2012) attempted to establish the effect of corruption on economic growth of sixty and seventy - one countries respectively. They used the random effect model and the General Method of 
Moment (GMM) with, though; the number of years used in the study was not stated. They found that both the results for the random effect model and the GMM results were relatively the same. The result revealed an inverted - U between corruption and economic growth while secondary school enrolment rate and gross foreign direct investment have positive and significant effect on economic growth. Primary school enrolment was found to impact on economic growth inversely.

Amin, Ahmed, \& Zaman (2013) used data for the period 1985 to 2010 to establish the relationship between corruption and economic growth in Pakistan. The variables used were all integrated of order one. They found that expenditure on education and population growth have significant positive relationship with economic growth while domestic investment and corruption have significant negative relationship on economic growth measured with per capita income. Ola, Mohammed and Audi (2014) provided an overview of the effect of corruption on the economic development of Nigeria. The authors noted that there has been significant corruption reduction in Nigeria as a result of the anti-corruption policies put in place, though, no empirical or statistical justification of the statement. They further noted that corruption demean the image of a country and loss of revenue. Mikaelsson \& Sall (2014) examined the relationship between corruption and economic growth of developing countries and data for 2002 to 2010 . The results showed that corruption did not have significant effect on economic growth of the developing countries while democracy impacted on economic growth inversely. Furthermore, education which they proxied by primary school completion rate and life expectancy were insignificant in the determination of economic growth, though, they have the expected positive sign. D'Amico (2015) considered corruption and economic growth in China provinces and an unbalanced panel. The author used GMM estimation method and found that all the variables; illiteracy, life expectancy, population, exports and foreign direct investment have the expected positive sign except corruption and population growth rate. They were all significant at $1 \%$ level of significance.

Thach, Duong, \& Oanh (2017) examined the impact of corruption on economic growth. They used data of 19 Asian countries in the period 2004 to 2015 and panel data estimation techniques. With the use of fixed effect, random effect and the dynamic general method of moment, they found that corruption has inverse impact on economic growth in Asian countries, though, they noted that bribe given speeds up administrative process. They further found that investment, population, democracy freedom and economic freedom have direct impact on economic growth. Ondo (2017) considered the relationship between corruption and economic growth in the Economic and Monetary Community of Central Africa and data within the period 2005 to 2015. They found that corruption, civil liberty, human capital and public spending have inverse relationship with economic growth in the community while private investment and commercial opening have positive relationship with economic growth. While civil liberty and private investment were significant at $1 \%$ level of significance, corruption was significant at $10 \%$ level of significance and noted that corruption may have a non-linear effect on economic growth.

Gründler \& Potrafke (2019) provided new empirical evidence on the link between corruption and economic growth of 175 countries and data for the period 2012 to 2018 and the use of GMM. They found that 
corruption and its lag values were consistently significant and negative in the determination of economic growth. The found that rail lines, net migration, interpersonal globalization and trade were significant and positive in the determination of economic growth while economic globalization was negatively significant.

Hoinaru, Buda, Borlea, Vaidean, \& Achim (2020) used panel of 185 countries and data set for the period 2005 to 2015 to test the "Sand the Wheels" and "Grease the Wheels" hypotheses of corruption by examining the impact of corruption and shadow economy on the economic and sustainable development. They used correlation matrix and found that most of the variable used were strongly correlated. The fixed effect and the random effect estimation result showed that the relationship between corruption and economic development was not consistent. However, they found an inverse relationship between corruption and the shadow economy on one hand and the same inverse relationship between corruption and economic development. The result supports the 'sands the wheel corruption hypothesis'.

Bitterhout \& Simo-Kengne (2020) did a panel analysis of the effect of corruption on then economic growth of BRICS countries. They used data from 1996 to 2014 and the fixed effect model and GMM estimation method to correct endogeneity problem. They established that corruption and economic growth have direct and significant relationship and long run equilibrium relationship existed among the variables used for the estimation. The coefficient estimate of investment was insignificant and did not meet the a priori expectation. Political stability, population growth rate and openness were not significant in the determination of economic growth, though were not significant while government consumption expenditure met the a priori expectation and was significant.

The objective of this paper is to empirically ascertain the relationship between corruption and economic growth in West Africa since empirical consensus is yet to be established while similar study has not been carried out in West Africa. It is also possible that the relationship between corruption and economic growth could be U-shaped which has not been tested in recent studies except Ahmed, et al (2012) to the best of my knowledge.

\section{METHOD}

Let a simple production function be stated as:

$Y_{i t}=f\left(L_{i t}, X_{i t}, V_{i t}\right), i=1,2, \ldots, 15$,

$t=2000,2001, \ldots, 2018$.

$Y_{i t}$ is real GDP; measure of economic growth of country $i$ at time $t$. $L_{i t}$ is labour force of country $i$ at time $t . X_{i t}$ is social and macroeconomic determinants like education proxied by primary school enrolment, foreign direct investment, unemployment and labour force of country $i$ at time $t . V_{i t}$ is corruption perception index of country $i$ at time $t$.

From (1), a Cobb-Douglas production function can be specified as:

$Y_{i t}=A_{i t} L_{i t}^{\lambda} X_{i t}^{\gamma} V_{i t}^{1-\lambda-\gamma}$

In equation (2), $A$ is used to capture the effects of other factors of production like other growth determinants used in the estimation. Though, Solow (1956) used $A$ to capture technological changes, and he also noted that $A$ could be the effect of other factors like war, natural disaster and even economic reforms.

Equation (2) can also be stated in log form as:

$L N Y_{i t}=L N A_{i t}+\lambda L N L_{i t}+\gamma L N X_{i t}+(1-\lambda-\gamma) L N V_{i t}$ (3) 
On the basis of (3), the estimated model is:

$L_{N R D G P_{i t}}=\eta_{0}+\eta_{1}$ LNPSENR $_{i t}+\eta_{2}$ LNODA $_{i t}$ $+\eta_{3} L N L B R F_{i t}+\eta_{4} L N F D I \quad+\eta_{5} L N C P I_{i t}$

$+\eta_{6} L N U N E M_{i t}+\mu_{i t}$

Where $L N$ before a variable is the log of that variable; $R D G P=Y$ is Real gross domestic product (GDP) measure of economic growth; PSENR $=X$ is Primary school enrolment, measure of human capital development; $O D A$ is Official Development Assistance; LBRF is Labour force; FDI is Foreign direct investment; $C P I=V$ is Corruption perception index; and UNEM is Unemployment rate.

All the data were sourced from World Development Indicators, 2018.

A priori, $\eta_{1}, \eta_{2}, \eta_{3}, \eta_{4} \succ 0 ; \eta_{5}, \eta_{6} \prec 0$.

The data used for the estimation ranged from 2000 to 2018. They were obtained from the World Bank Development Indicators (2018). Each of the variables is explained below:

RGDP is real gross domestic product, purchasing power parity that is; GDP, PPP (Constant 2011 international US Dollar, \$). It is a standard measure of the volume of GDP of countries or regions. It can be calculated by dividing real GDP by the corresponding purchasing power parity, which is an exchange rate that removes price level differences between countries.

PSENR is primary school enrolment represents human capital development. It is the total primary school enrolment (boys and girls) in primary school. It is the ratio of children of the official primary school age who are enrolled in primary school to the total population of the official primary school age.

ODA is official development assistance. This is net official development assistance and official aid received at 2013 constant US Dollars, \$. Net official development assistance consists of disbursements of loans made on concessional terms (net of repayments of principal) and grants by official agencies of the members of the Development Assistance Committee (DAC), by multilateral institutions. On the other hand, net official aid received refers to aid flows (net of repayments) from official donors to countries.

LBRF is total labour force. It comprises of people of ages 15years and above who supply labour for the production of goods and services during a specified period.

CPI is corruption perception index of each country. It measures the rates of countries' perceived level of corruption on a scale from o (highly corrupt) to 10 (clean).

The stationarity test was done with the Im, Pesaran \& Shin (2003) method. The test allows for heterogeneous version of the Dickey Fuller test (Hall \& Mairesse, 2002) and can be stated as:

$$
x_{i t}=\gamma+\beta_{i} x_{i, t-1}+\varepsilon_{i t} ; i=1,2, \ldots, 15 \text {; }
$$$$
t=2000,2001, \ldots, 2018
$$

Where:

$\gamma=\left(1-\beta_{i}\right) \alpha_{i}$

$x_{i t}=\gamma+\lambda t+\beta_{i} x_{i, t-1}+\varepsilon_{i t} ;$

Where:

$\gamma$ is as earlier defined

$\lambda=\lambda=(1-\beta i) \phi_{i}$

The panel co-integration method by Pedroni (1999, 2004) was used to establish long run relationship among the variables and can be stated as:

$$
\begin{aligned}
& y_{i, t}=\eta_{i}+\sum_{n=1}^{k} \beta_{n i} x_{i t}+\mu_{i, t} \quad \text { for } i=1,2, \ldots, 15 ; \\
& t=2000,2001, \ldots, 2018
\end{aligned}
$$


Where $i$ and $t$ are respectively the cross section and the number of observations. The panel cointegration test is based on within-dimension or between-dimension statistic. The within-dimension based statistics are referred to as panel cointegration statistics while betweendimension statistics are considered as groupmean co-integration statistics. As noted by Quyoom \& Imran (2012), the main strength of the Pedroni test is that it allows for individual member-specific fixed effects, deterministic trends and slope coefficients.

The estimation was carried out with the use of the fully modified ordinary least squares (FMOLS) method first introduced by Pedroni (2000). The method takes into account both the serial correlation and endogeneity problems that may be present in the variable which is not case in the ordinary least squares and can modelled as:

$$
\begin{aligned}
& Y_{i t}=\beta_{i}+\varpi X_{i t-1}+\varepsilon_{i t}+v_{i t} \\
& { }^{*}{ }_{N T}=N^{-1} \sum_{t=1}^{N}(\Omega)(\Phi)
\end{aligned}
$$

Where: $\Omega=\sum_{i=1}^{T}\left(X_{i t}-\overline{x_{i}}\right)^{-1}$

$$
\Phi=\sum_{i=1}^{T}\left(X_{i t}-\bar{X}_{i}\right)^{2} Y_{i t}^{*}-T \tau_{i}
$$

Where $v$ and $\mu$ are respectively error terms and are assumed to be stationary. The panel fully modified estimator for $\varpi$ can be modelled as:

$$
\stackrel{*}{Y}_{i t}=\left(Y_{i t}-\bar{Y}_{i}\right)-\frac{\hat{L}_{21 i}}{\hat{L}_{22 i}} \Delta X_{i t}
$$

Where: $\tau_{i}=\hat{\Gamma}_{21 i}+\mathrm{B}_{21 i}^{0}-\frac{\hat{L}_{21 i}}{\hat{L}_{22 i}}\left(\hat{\Gamma} 22 i-\mathrm{B}_{22 i}^{0}\right)$

(8)

Where: $\mathrm{B}_{i}=\mathrm{B}_{i}^{0}+\Gamma_{i}+\Gamma_{i}^{\bullet}$ is the covariance matrix; $\mathrm{B}_{\mathrm{i}}{ }^{\mathrm{o}}$ is the contemporaneous covariance; $\Gamma_{\mathrm{i}}$ is the weighted sum of covariance; $L_{i}$ is the lower triangular in the decomposition of $\mathrm{B}_{\mathrm{i}}$

\section{RESULTS AND DISCUSSION}

Table 1 presents the panel stationarity results using the Im, Pesaran and Shin

Table 1. IPS Panel Stationarity Result

\begin{tabular}{lclcccc}
\hline \multirow{2}{*}{ Variable } & \multicolumn{3}{c}{ Individual Effects } & \multicolumn{2}{c}{ Individual Intercept and Trend } \\
\cline { 2 - 6 } & Stat. & Probability & Remark & Stat. & Probability & Remark \\
\hline LNRGDP & -0.75350 & 0.2256 & Non & 0.51155 & 0.6955 & Non \\
& & & stationary & & & stationary \\
D(LNRGDP) & -5.66215 & $0.0000^{* * *}$ & $\mathrm{I}(1)$ & -6.19437 & $0.0000^{* * *}$ & $\mathrm{I}(1)$ \\
LNPSENR & -1.12976 & 0.1293 & Non & 1.79251 & 0.9635 & Non \\
& & & stationarity & & & stationarity \\
D(LNPSENR) & -4.32846 & $0.0000^{* * *}$ & $\mathrm{I}(1)$ & -3.96906 & $0.0000^{* * *}$ & $\mathrm{I}(1)$ \\
LNODA & 0.54632 & 0.7076 & Non & -0.43137 & 0.3331 & Non \\
& & & stationary & & & stationary \\
D(LNODA) & -5.57445 & $0.0000^{* * *}$ & $\mathrm{I}(1)$ & -4.19422 & $0.0000^{* * *}$ & $\mathrm{I}(1)$ \\
LNLBRF & -0.19789 & 0.4216 & Non & 0.83395 & 0.7978 & Non \\
& & & stationary & & & stationary \\
D(LNLBRF) & -1.78801 & $0.0369^{* *}$ & $\mathrm{I}(1)$ & -2.53103 & $0.0057^{* *}$ & $\mathrm{I}(1)$ \\
\hline
\end{tabular}




\begin{tabular}{lllcllc}
\hline LNFDI & -0.25554 & 0.3992 & $\begin{array}{c}\text { Non } \\
\text { stationary }\end{array}$ & 2.08237 & 0.9813 & $\begin{array}{c}\text { Non } \\
\text { stationary }\end{array}$ \\
D(LNFDI) & -5.42576 & $0.0000^{* * *}$ & $\mathrm{I}(1)$ & -3.55453 & $0.0002^{* * *}$ & $\mathrm{I}(1)$ \\
LNCPI & 0.42865 & 0.6659 & Non & -1.01747 & 0.1545 & Non \\
& & & stationary & & & stationary \\
D(LNCPI) & -7.22523 & $0.0000^{* * *}$ & $\mathrm{I}(1)$ & -5.04303 & $0.0000^{* * *}$ & $\mathrm{I}(1)$ \\
LNUNEM & -0.07205 & 0.4713 & Non & -0.24927 & 0.4016 & Non \\
& & & stationary & & & stationary \\
D(LNUNEM $)$ & -4.04265 & $0.0000^{* * *}$ & $\mathrm{I}(1)$ & -2.03559 & $0.0209^{* *}$ & $\mathrm{I}(1)$ \\
\hline \multirow{2}{***}{$(* *)$ significant at $(1 \%)(5 \%)}$.
\end{tabular}

Using the individual effects as well as individual intercept and trend, all the variables were not stationary at levels but became stationary after first differencing. This implies that the variables were all of order one, that is $\mathrm{I}(1)$

Out of the seven different statistics for this test, the Phillips Perron (PP) statistics and the Augmented Dickey Fuller (ADF) statistics were used to determine long run relationship. The result as shown in Table 2 reveals that cointegration relationship exists among the variables.

Table 2. Pedroni Cointegration Results

\begin{tabular}{ccc}
\hline & $\begin{array}{c}\text { Within } \\
\text { Dimension }\end{array}$ & $\begin{array}{c}\text { Between } \\
\text { Dimension }\end{array}$ \\
\hline PP - & $-3.127008^{* * *}$ & $-7.618006^{* * *}$ \\
Statistics & & \\
ADF & $-2.000571^{* *}$ & $-7.618006^{* * *}$ \\
Statistics & & \\
\hline$* * *(* *)$ significant at $(1 \%)(5 \%)$ &
\end{tabular}

Table 3. Panel FMOLS Result

Dependent Variable: LNRGDP

Panel (FMOLS)

(A)

(B)

Linear Estimation

\begin{tabular}{lrr}
\hline LNPSENR & $1.383701^{* * *}$ & $1.367887^{* * *}$ \\
& $(6.731397)$ & $(6.852146)$ \\
LNODA & $0.389758^{* * *}$ & $0.415414^{* * *}$ \\
& $(8.147296)$ & $(8.810423)$ \\
LNLBRF & $2.576171^{* *}$ & $1.934027^{*}$ \\
& $(2.185826)$ & $(1.662081)$ \\
LNFDI & 0.067982 & -0.096437 \\
& $(0.6964)$ & $(-0.549617)$ \\
LNCPI & $0.563435^{* * *}$ & $-4.116935^{* *}$ \\
& $(4.406182)$ & $(-2.408937)$ \\
LNCPI^^${ }^{2}$ & & $0.696312^{* *}$ \\
LNUNEM & & $(2.737410)$ \\
& & -0.038258 \\
$\mathrm{R}^{2}$ & -0.036260 & $(-0.502417)$ \\
Adj. $\mathrm{R}^{2}$ & $(-0.462133)$ & 0.964699 \\
\hline
\end{tabular}

$* * *(* *)^{*} 1 \%(5 \%) 10 \%$ sig. respectively. ( ) the t-statistic 
The panel FMOLS shows that all the control variables were significant in the determination of economic growth except FDI and unemployment rate. Both estimations (linear and quadratic) showed that primary school enrolment (LNPSENR) proxy for human capital development was significant at one percent level of significance and has direct influence on economic growth of West Africa. The result showed that a one percent increase in primary school enrolment, which is improved human capital, would increase economic growth by about $1.4 \%$ respectively in both estimations. The result is contrary to the one obtained by Amed, et al (2012) who found primary school enrolment to impact on economic growth inversely contrary to the one established when they attempted to establish the effect of corruption on economic growth of sixty and seventy - one countries with the use of panel data [the random effect model and the General Method of Moment (GMM)].

Contrary result was also found by Ondo (2017) who found negative but significant relationship between human capital development and economic growth in his study of the relationship between corruption and economic growth in the Economic and Monetary Community of Central Africa and data within the period 2005 to 2015. The result further confirmed the one obtained by Nelson \& Phelps (1966) who noted that educated workforce may better understand the use of technology compared to uneducated one as this will further boost economic growth in their study of investment in humans, technological diffusion and economic growth. Nelson \& Phelps (1966) used two models of technological diffusion, that is a production function with labour augmenting with the assumption that technical progress is wholly disembodied and the second model which states the rate at which the latest theoretical technology is realised in improved technological educational practice which shows the importance of educational attainment. Similarly, Bils, \& Klenow (2000) used a model that is calibrated to quantify the strength of the effect of schooling on growth by using evidence from the labour literature on Mincerian returns to education. They constructed construct human capital stocks for individuals of each age between 20 and 59, using (13) and incorporating schooling, experience, and teacher human capital specific to each age for as many countries they could get. They opined that high enrolment rate leads to faster improvement in productivity which means that faster growth in real gross domestic product resulted from countries with high enrolment in schools. The results further reinstated the importance of education in enhancing economic growth as earlier noted by (Schultz, 1961).

ODA has significant and direct influence on economic growth and showed that an increase in ODA by say, one percent will increase economic growth by less than one percent in both estimations. It affirms the earlier one obtained by Moolio \& Kong (2016) when they applied panel fully modified ordinary least squares (FMOLS) and panel dynamic ordinary least squares (DOLS) estimators to determine the magnitude of long run relationship between foreign aid and economic growth in Cambodia, Lao PDR, Myanmar, and Vietnam using panel data from 1997 to 2014. They found positive and significant link between official development assistance and economic growth in the four Asian countries.

Labour force (LNLBRF) also significantly impacted on economic growth. An increase in labour force by about one percent will increase economic growth by less than three percent while foreign direct investment has mixed result in terms of the signs of the parameter estimates in the linear and quadratic estimations. However, the positive result confirms the earlier one obtained by D'Amico (2015) who found 
positive and significant relationship between FDI and economic growth.

With respect to corruption variable, there was a mixed result with respect to the parameter estimates on the linear and nonlinear models. The result of the linear model showed that corruption has direct influence on economic growth and that an increase in corruption perception index by one percent will increase economic growth by less than one percent. The result affirms the one earlier obtained by Ahmad, Ullah, \& Arfeen (2012) for 60 developed and developing countries as well as 71 developed and developing economies. This result further ascertained the theory of Leff (1964) who opined that corruption is oil that greases the wheels of government. Those in favour of the greasing hypothesis argued that corruption facilitates trade that may not have happened otherwise and that it promotes efficiency by allowing private sector agents to circumvent cumbersome regulations, hence, promotes economic growth. However, those opposing this view noted that the greasing effect of corruption is only possible as a second best option in a bad institutional setting (Campos \& Dimova, 2010). It is contrary to the result obtained by Boussalham (2018) and Tidiane (2019, Ondo (2017), Grindler et al (2019) and Bitterhout (2020) who found inverse relationship between corruption and economic growth.

In the non-linear estimation, corruption variable exhibited u-shape. It shows an inverse relationship with economic growth, gets to a critical lower level and later impacts positively, which implies that different level of corruption affect economic growth differently. It implies that initially, corruption will impact inversely on economic growth through bribe taking which may lead to unfair competition and may prevent new opportunities and promote rent seeking.
After a while the negative impact may get to a critical level where for example, the same bribery will help to overcome unnecessary government regulations and red tapism. Red tapism refers to over regulation also known as rigid conformity to formal rules that are bureaucratic which may prevents action or decision-making process. Rigid conformity lends credence to inefficient officials who take bribes for services that are supposed to be free. Red tape may be frustrating; however, it sometimes provides social benefits. Red tape does not come up because of incompetence of bureaucrats but to ensure that government processes are representative and accountable and to meet the demands, often fragmented, of citizens and interest groups (Anti-Corruption Digest International, 2018).

\section{CONCLUSION}

The paper empirically examined the relationship between corruption and economic growth in fifteen West Africa countries. Data for the period 2000 to 2018 and the panel fully modified ordinary least squares were used for the estimation. The variable used were integrated of order one and there is cointegration relation among the variables. Labour force was the most important variable that impacts on economic growth positively in terms of the parameter estimate. With respect to the linear estimation, corruption has direct relationship with economic growth thereby supports the hypothesis that corruption greases the wheels of economic growth rather than sand the wheels of economic growth. As per the quadratic estimation, the U-shaped relationship between corruption and economic growth was supported.

Based on the results estimates, the following are recommended. Official development assistance to West African 
countries should be effectively managed in such a way that it is not misused for activities that are not necessary through corrupt act. In addition, labour force should be encouraged through incentive like increased salaries and allowances as this will directly impact on economic growth. Rising unemployment in the region should be curtailed through programs that will encourage self employment like skill development. Though, from the result, corruption impacts on economic growth positively, it may not lead to efficient outcomes because of cutting of corners and probably breaches of protocols. Therefore, corruption should not be encouraged at any level of governance. Interest group or political influences should not be taken into consideration when fighting corruption at any level. Most importantly, offenders should be brought to book through constitutional means.

\section{REFERENCES}

Ahmad, E., Ulla, M. A. \& Arfeen, M. I. (2012). Does corruption affect economic growth? Latin American journal of economics, 49(2), 277-305.

Akers, R. L., \& Sellers, C. S. (2009). Criminology theories (5th ed.). NY: Oxford University Press.

Amin, M., Ahmed, A. A., \& Zaman, K. (2013). The relationship between corruption and economic growth in Pakistan Looking beyond the incumbent. Oeconomics of knowledge, 5(3), 16 45 .

Anti-Corruption Digest International (2018). Red tape: dynamics of corruption. Anti-corruption digest international risk \& compliance news. April 5th. Available https://anticorruptiondigest.com/2018/o 4/o5/red-tape-dynamics-of-corruption/

Ayee, J. (2002). Political and social consequence of corruption: In Corruption and development in Africa. Proceedings of a Seminar Organized by the Ghana Academy of Arts and Sciences with Friedrich Ebert Foundation, June.

Bitterhout, S. \& Simo-Kengne, B.D. (2020). The effect of corruption on economic growth in the BRICS countries. A panel data analysis. Economic development and well-being research. EDWRG Working Paper Series, Working Paper Number 03-2020, 1 - 23. January

Bernard, T. J., Snipes, J. B., \& Gerould, A. L. (2010). Vold's theoretical criminology (6th ed.). York, NY: Oxford University Press. Blasius, J., \& Brandt, M. (2010). Representatives in online surveys through stratified samples. Bulletin de Methodologie Sociologique, 107, 5-21.

Booth, D. (2012). Development as a collective action problem: Addressing the real challenges of African governance. Synthesis Report of the Africa Power and Politics Programme. London: ODI.

Boussalham, H. (2018). The consequences of corruption on economic growth in Mediterranean countries: Evidence from Panel data analysis. Available at: doi:10.20944/preprints201802.0065.v3

Brunetti, A., \& Weder, B. (2003). A Free Press is Bad News for Corruption. Journal of Public Economics, 87, 1801-1824.

Campos, N. \& Dimova, R. (2010). Corruption does sand the wheels of growth. The Centre for Economic Policy Research, CEPR Policy Portal. Available at: https://voxeu.org/article/doescorruption-sand-or-grease-wheelseconomic-growth 
Corruption Perceptions Index (2018). Transparency International: The Global Coalition against Corruption. Available at: www.transparency.org/cpi

D'Amico, N. (2015). Corruption and economic growth in China: An empirical analysis. Corruption and Economic Growth in China: An empirical analysis. Senior honours projects. 78. Available at: http://collected.jcu.edu/honorspaper $\mathrm{s} / 78$

De Graaf, G. (2003). Causes of corruption: towards a contextual theory of corruption. Available at: http://unpanı.un.org/intradoc/group s/public/documents/undpadm/unpano49603.pdf.

Gorai, M. G. (2016). Foundational understanding of corruption. Available at: https://chs.uonbi.ac.ke/sites/default/ files/chs/chs/CHS\%20-\%2017-o62016\%20-

\section{CONCEPT\%20OF\%20CORRUPTION} .pdf

Gould, S. J. (2002). The structure of evolutionary theory. Cambridge: Harvard University Press.

Granovetter, M., (1992). Economic institutions as social constructions: A framework for analysis. Acta Sociologica. 35, 3-11. Available at: http://asj.sagepub.com/content/35/1/ 3.short

Gründler, K., \& Potrafke, N. (2019). Corruption and economic growth: New empirical evidence. ifo working papers, 301, 1-35

Hall, B. H., \& Mairesse, J. (2002). Testing for unit roots in panel data: Available at: https://eml.berkeley.edu/ bhhall/paper s/HallMairesseJano3\%2ounitroot.pdf

Hoinaru, R., Buda, D., Borlea, S.N., Vaidean, V.L., \& Achim, M.V. (2020). The impact of corruption and shadow economy on the economic and sustainable development. Do they "sand the wheels" or "grease the wheels"?. Sustainability. $12(481), 1-27$.

Huberts, L., Kaptein M, \& Lasthuizen, K. (2004). Leadership and integrity violations at work: A study on the perceived impact of leadership behaviour on integrity violations within the Dutch Police Force. Paper presented at IRSPM VIII, Budapest.

Hulten, M. (2002). Corruptie, Onbekend, Onbemind, Alomtegenwoordig. Amsterdam: Boom.

Im, K.S., Pesaran, M.H., \& Shin, Y. (2003). Testing for Unit Roots in Heterogenous Panels. Journal of Econometrics, 115, 5374 .

Jackall, R. (1988). Moral mazes: The world of corporate managers. New York: Oxford University Press.

Johnson, M. (1998). Fighting systemic corruption: Social foundations for institutional reform. European Journal of Research, 10(1), 85-105.

Johnston, M. (2000). Corruption and democratic consolidation. Available at: http://citeseerx.ist.psu.edu/viewdoc/do wnload?doi=10.1.1.203.1955\&rep=rep1\&ty pe $=$ pdf

Klitgaard, R. (1988). Controlling corruption. Berkeley: University of California Press.

Leff, N. (1964). Economic development through bureaucratic corruption. The American behavioural scientis,. 8, 8-14. 
Lo, T.W. (1993). Corruption and Politics in Hong Kong and China, Open University Press: Buckingham.

Mauro, P. (1998). Corruption and the composition of government expenditure. Journal of Public Economics. 69, 263-279.

Mikaelsson, A., \& Sall, S. (2014). Does corruption have a significant effect on economic growth? An empirical analysis examining the relationship between corruption and economic growth in developing countries. 1- 40. Available at: www.diva-portal.org , divaz:783809 > FULLTEXTo1

Mo, P.H. (2001). Corruption and economic growth. Journal of comparative economics. 29, 66-79

Moolio, P., \& Kong, S. (2016). Foreign aid and economic growth: panel cointegration analysis for Cambodia, Lao PDR, Myanmar and Vietnam Athens institute for education and research (ATINER), 2(4), 417- 428.

Nelson, R. R. \& Phelps, E. S. (1966). Investment in humans, technological diffusion and economic growth" American economic review, 56(2), 6975 .

Nye, J. S. (1979). Corruption and political development: A cost-benefit analysis. American political science review, 61(2), 417- 427

Ola, A.S., Mohammed, A. \& Audi, M.S. (2014). Effects of corruption on economic development in Nigeria. Global journal of interdisciplinary social sciences. 3(3), 209 - 215

Ondo, A. (2017). Corruption and economic growth: The case of EMCCA. Theoretical economics letters. 7, 1292-1305
Pedroni, P. (1999). Critical values for cointegration tests in heterogeneous panels with multiple regressors. Oxford bulletin of economics and statistics 61 , 653-670.

Pedroni, P. (2000). Fully modified OLS for heterogeneous cointegrated panels. Advances in econometrics. 15, 93-130

Pedroni, P. (2004). Panel cointegration: asymptotic and finite sample properties of pooled time series tests with an application to the PPP hypothesis. Econometric theory 20, 597-625.

Punch, M. (2000). Police corruption and its prevention". European journal on criminal policy and research. 8, 301-324.

Quyoom, K. A. and Khan, M. I. (2012). Determinants of FDI inflows to developing countries: a panel data analysis. Munich Personal RePEc Archive (MPRA) Paper No. 37278 Available at: https://mpra.ub.unimuenchen.de/37278/

Ribadu, N. (2009). Capital loss and corruption: The example of Nigeria. Testimony before the House Financial Services Committee. Available at: http://www.cgdev.org/doc/Opinions/Ri badu_corruption_05-19-09.pdf.

Rose-Ackerman, S. (1978). Corruption: A study in political economy. New York: Academic Press.

Saha, S.,\& Gounder, R. (2013). Corruption and Economic Development Nexus: Variations Across Income Levels in a Non-linear Framework. Economic Modelling, 31, 70-79.

Saha, S., \& Sen, K. (2019). The corruptiongrowth relationship do political institutions matter? WIDER working paper 2019/65. United Nations University, UNU-WIDER. Pp. 1 - 19. 
Schultz, T.W. (1961). Investment in human capital. The American economic review. 51(1), 1-17.

Seldadyo, H., \& de Haan, J. (2006). The determinants of corruption a literature survey and new evidence. Paper presented at the 2006 EPCS Conference, Turku, Finland, 20-23 April

Singer, S. D., \& Hensley, C. (2004). Applying social learning theory to childhood and adolescent fire-setting: Can it lead to serial murder? International Journal of Offender Therapy and Comparative Criminology, 48, 461. Available http://www.ijo.sagepub.com

Steenbeek, W., \& Hipp, J. R. (2011). A longitudinal test of social disorganization theory: Feedback effects among cohesion, social control, and disorder. Criminology, 49(3), 833-871.

Solow, R. M. (1956). A contribution to the theory of economic growth" Quarterly journal of economics. 70, 65-94.

Steenbeek, W., \& Hipp, J. R. (2011). A longitudinal test of social disorganization theory: Feedback effects among cohesion, social control, and disorder. Criminology, 49(3), 833-871.

Svensson, J. (2005). Eight questions about corruption, Journal of economic perspectives, 19(3), 19-42.

Thach, N. N., Duong, M. B., \& Oanh, T. T. K. (2017). Effects of corruption on economic growth - empirical study of Asia countries. Imperial journal of interdisciplinary research (IJIR). 3(7), $791-804$.
Theobald, R., \& Williams, R. (1999). Combating corruption in Botswana: Regional role model or deviant case?" Commonwealth and comparative politics. 37, 117-134.

Teveik, F. N., Albert, C. P., \& Charles, S. (1986). A policy-oriented theory of corruption. American Political science review, University of Michigan Flint, USA.

Tidiane, N. C. (2019). Corruption, investment and economic growth in WAEMU countries. International journal of economics and finance. 11(4), $30-39$.

World Bank (1997). Helping combat corruption: The Role of the World Bank, World Bank. Washington DC

World Development Indicators, WDI (2018). Data Base. Available at: http://datatopics.worldbank.org/worlddevelopment-indicators/ 